\title{
Paradigm Of Judicial Verdict
}

\author{
Amiek Soemarmi, Erlyn Indarti, Pujiyono \\ Doctoral Program in Law Science of Diponegoro University \\ JL. Imam Bardjo, SH. No. 1 Semarang, Jawa Tengah, 50241 \\ amiekhk@yahoo.com
}

\begin{abstract}
A judge holds a paradigm that greatly influences the way in which reality is perceived. Grasping the meaning of reality will create a relationship between the judge itself, a paradigm follower, with a comprehended reality in which it will create a methodology for the solving the problem of the reality. Unconsciously, the paradigm will affect a judge in applying discretion. The discretion applied by one judge to another will be different. The difference is based on the diversity of its paradigm that will lead to disparity in the judicial verdict. The disparity in judicial verdicts occurs because of the paradigm of a judge embedded in himself. The paradigm of a judge will influence the extent to which discretionary constraints are applied. The diversity of paradigms adopted by judges will make a difference regarding to the limitation in applying discretion resulting the disparities in judicial verdicts. This study uses paradigm study in a qualitative research as the initial determinant where the dynamic variable is not always static. Construtive paradigm will guide the writer in doing the translation of data obtained through interview and other observation methods.
\end{abstract}

Keywords: paradigm, judge, judicial verdict.

\begin{abstract}
ABSTRAK
Seorang Hakim menganut paradigma yang sangat mempengaruhi terhadap cara memandang realitas, setelah menangkap makna dari realitas maka akan tercipta hubungan antara hakim itu sendiri selaku penganut paradigma tertentu dengan realitas yang dipahami, dimana keterkaitan itu akan menciptakan metodologi untuk menyelesaukan masalah-masalah terhadap realitas tersebut. Tanpa disadari paradigma tersebut akan mempengaruhi seorang hakim dalam menerapkan diskresi. Diskresi yang diterapkan seorang hakim yang satu dengan yang lainakan berbeda. Perbedaan tersebut dilandasi atas keberagaman paradigma yang dianutnya, perbedaan paradigma tersebut akan terjadi disparitas dalam putusan hakim. Disparitas putusan hakim terjadi karena paradigma seorang hakim yang tertanam pada dirinya sendiri. Paradigma seorang hakim akan mempengaruhi sejauh mana batasan diskresi yang diterapkan, dengan keberagaman paradigma yang dianut hakim akan menimbuklkan perbedaan mengenai batasan penerapan diskresi sehingga menghasilkan disparitas dalam putusan hakim. Penelitian ini menggunakan kajian paradigma dengan menggunakan penelitian kualitatif sebagai penentu awal dimana variabel bersifat dinamis yang tidak selamanya statis. Paradigmna konstruktivisme akan memandu penulis dalam melakukan penerjemahan data yang diperoleh melalui metode wawancara dan pengamatan lainnya.
\end{abstract}

Kata Kunci: paradigma, hakim, putusan hakim. 
Vol 2, No. (2019): Law, Development \& Justice Review, Mei 2019. e-ISSN: 2655-1942

\section{INTRODUCTION}

The tangible realization of Judicial Power as regulated in Article 24 of the 1945 Constitution of the Republic of Indonesia is the power to run a judicial function for every legal matter brought by the parties to justice. There are two forms of legal products issued by the court, namely: "verdict" and "decision". The verdict and decision are pronounced in a hearing open to the public by a judge as State official ${ }^{1}$ authorized by law to do so. The verdict is the product of the judiciary in resolving disputes occurring in the community, both in the civil (public and religious), the relationship between the state and its citizens over the violation of the rules of criminal law as well as the administrative relationship between the government apparatus and the public upon the issuance of a state administrative decree. Meanwhile, in another function, the court decision is also a legal institution in the process of legal education for the community, the rules contained in the considerations should reflect constructive values as learning for the community; for example, the prevention of applicable law is conducted by not excluding the application of local wisdom values applied in each region.

The position of the judge in making the verdict plays a very important role in the process of creating disparity in the verdicts. The disparity of the verdicts created is a long process result of discretion. Disparities in the verdict do not just happen without a clear reason. Each judge will have his or her own view of the extent of discretion. However, the boundaries in applying this discretion are highly dependent on the paradigm of the one who holds it. PurnadiPurbacaraka and SoeryonoSoekanto argued that judges have the discretion freely, his feelings about what is right and what is wrong is the real guidance to achieve justice ${ }^{2}$.

Currently, in the development of constitutional law, several special courts have been known, both fixed and ad hoc, namely:

1. Human Rights Court;

2. Corruption Court;

3. Commercial Court;

4. Juvenile Court;

\footnotetext{
${ }^{1}$ See Article 11 of Law No. 43/1999 on the Fundamentals of Civil Service in Letter Mentioned that Judges are Public Servants in the Category of State Officials.

${ }^{2}$ Purnadi Purwacaraka \& Soeryono Soekanto, Renungan Tentang Filsafat Hukum, Jakarta, 1985, p.26
} 
Vol 2, No. (2019): Law, Development \& Justice Review, Mei 2019. e-ISSN: 2655-1942

\author{
5. Fishery Court; \\ 6. Industrial Labor Court; and \\ 7. Tax Court.
}

The existence of special courts established within a court, the structure within the judiciary becomes more complex and may affect the quality of human resources who play a role in law enforcement, especially for examinations in court hearings, which have career judges and ad hoc judges in special courts under general courts. ${ }^{3}$

It is common to find differences in judicial verdicts which are called disparities. Disparities occur because of the underlying differences. One thing that may affect the difference is the paradigm the judges hold. Therefore, the judge's paradigm is related and influence each other in doing the discretion before the case is pronounced until there is disparity done by the judge after a verdict is pronounced. Therefore, the research question proposed in this writing is how can discretion and disparity in the judicial verdicts be understood through the paradigmatic study.

\title{
METHODOLOGY
}

Research method is essentially a scientific way of getting information as it is instead of as it should be. The fact achieved are mostly verified data which are unlike as expected. To obtain the results of scientific research, it needs scientific ways or methods as well. This research requires accurate data both primary and secondary data. The data are obtained through research method. Primary data are obtained from field research through direct observation of phenomena or social phenomena studied by conducting interviews with key informants.

\section{DISCUSSION}

The judge, the last pillar in which law is depicted working on the functioning of a judicial system, is considered a personal who is obliged to have a living and functioning conscience. The judge is always challenged to continuously rise the conscience towards the case he/she faces. The inherent paradigm of the judge will determine the extent to which the conscience can participate in understanding the reality of the law he/she is

\footnotetext{
${ }^{3}$ Amiek Soemarmi, Pembentukan Pengadilan Perikanan Sebagai Upaya Pelaksanaan Penegakan Hukum di Bidang Perikanan, Research Result in the Faculty of Law, Diponegoro University, 2012, p. 30
} 
facing. Positivism believers, for example, will ignore away the factor of "conscience" within him/herself to be involved in cases that are faced to him/her.

Judges are often faced with the difficult choice, for example when the justice and legal certainty cannot be summarized in a conclusion. Those two principles should ideally be matched in a verdict, but combining justice and legal certainty in reality is not easy. ${ }^{4} \mathrm{Judges}$ are appointed and dismissed by the President with decree. Besides carrying out the mandate of the law, judge is also an extension of God's hand to uphold truth and justice based on the values of Belief in the Almighty.

The freedom of a judge in prosecuting a case is protected by law. Every form of actions or deeds that are insulting, degrading and influencing the judiciary either directly or indirectly in the functions and duties to enforce the law and justice is an offense and is a form of contempt of court. ${ }^{5}$ The Law No. 48/2009 Article 3 Paragraph (2) states that "any interference in the affairs of the judiciary by any other party outside the judicial authority is prohibited except in the case referred to in the 1945 Constitution of the State of the Republic of Indonesia." Furthermore, in paragraph (3) it is stated: "Any person who knowingly violates the provisions referred to in paragraph (2) shall be punished in accordance with the provisions of laws and regulations."

The consequence of the prohibition for a judge to refuse the case for an examination because there is no or less clear law is that the judge is equipped with the authority to interpret the law. Interpretation is a process of reasoning that aims to:

1. understand the meaning of the principle or rule of law;

2. relate the legal fact with the rule of law;

3. guarantee the implementation or law enforcement to be done properly;

4. match the rule of law with social changes so that the rule of law remain actual and be able to meet the needs which are in accordance with the community changes. ${ }^{6}$

Furthermore, in relation to the authority of interpretation, a judge faces several matters, such as:

\footnotetext{
${ }^{4}$ The statement is delivered by the Head of Supreme Court in A Day Seminar of Problem Hukum Keluarga Antara Realita dan Kepastian Hukum cited from Varia Peradilan, XXIV edition, No.: 286 September 2009, p.7 ${ }^{5}$ Indriyanto Seno Adji, Humanisme dan Pembaharuan PenegakanHukum, Jakarta, Kompas, 2009, p. 12 showed that Contempt of court can be interpreted to insist an act or omission substantially disrupting the judicial process in a particular case covering 2 types, namely: "contempt in facie" and "contempt ex facie". ${ }^{6}$ Bagir Manan, Beberapa Catatan tentang Penafsiran, Judicial varia No. 285, August 2009, p. 5-6.
} 
"Firstly, the judge must decide upon the law. Each verdict must be based on certain legal rules that existed at the time a legal event occurred (instead of the time about to decide). Secondly, the judgeis prohibited from refusing to decide upon reasons of unavailability of existing rules of law or unclear rules.

Thirdly, the judge should decide quickly to remember the expression that says justice delayed, justice denied."7

A judge shall settle any legal dispute submitted to him in a wise and prudent manner, in accordance with the legal jurisprudence that applies according to the rules of positive law and the existing conditions of community. Judges are required to explore and understand the values and norms that exist and thrive in a legal community alliance. The law should not be interpreted as a law only but the law is a manifestation of all forms of good rules that have been legitimated by the power of the State and which are still in the form of norms, which are scattered in the social life of the community. Satjipto Rahardjo cited from Antonius Sudirman's ${ }^{8}$ book stated that the law always has some disadvantages, such as:

1. His rigidity. This deficiency actually will appear shortly in connection with legislation to show certainty. When this certainty is about to be fulfilled, he will have to make clear, detailed and firm formulations in which the risk becomes rigid norms;

2. The desire of legislation to create general formulations leads a risk that it ignores and thus forces the differences and/or special features that cannot be generalized for granted. Particularly in the atmosphere of quite complex modern life and specialty, we are not in easy way to make placements (generalization).

When a law enforcement is dealing with a case or problem in the community, independence and the authority inherent in it make it possible to be able to perform at once different kinds of work wisely and thoughtfully; ${ }^{9}$

1. Reading the case or problem well.

2. At the same time, translating the existing law in a comprehensive manner, it is especially applied to some cases that can be directly done as granted in black and white.

3. In most other cases, it is sometimes required to interpret laws that have been further translated.

\footnotetext{
${ }^{7}$ Ibid, p. 6.

${ }^{8}$ Antonius Sudirman, Hati Nurani Hakim dan Putusannya, Bandung, PT Citra Aditya, 2007, p. 59.

${ }^{9}$ Erlyn Indarti, Diskresi dan Paradigma, Semarang, Badan Penerbit Universitas Diponegoro, 2010, p.37.
} 
Vol 2, No. (2019): Law, Development \& Justice Review, Mei 2019. e-ISSN: 2655-1942

When the work is collided with each other, the next work to do is:

4. Sorting out both cases that have been read and the law that has been translated and/or interpreted.

5. Selecting and setting options.

Those are two more second-line things to do that are expected to be enforced by a law enforcer when they face a case or problem. Meanwhile, the two more third-line things to do following the above choices are:

1. Making a decision or conclusion

2. Take certain actions or steps.

Therefore, a law enforcer in conducting his/her duties,such as making decisions or whatever steps are taken essentially has gone through a long process with full "professional judgment." The whole series of processes that take place within a fairly wide space of motion are called discretion.

Some definitions of discretion: ${ }^{10}$

Oxford: the Australian reference Dictionary (1992) defines discretion as:

"Freedom or authority of person to act in accordance with his/her assessment/judgement."

Oxford: Advanced Learner's Dictionary (2010) defines discretion as:

"The freedom or power to decided what should be done in a particular situation."

Comprehending the aforementioned description may identify 8 (eight) elements of all meaning derivatives contained in the sense of discretion, namely: ${ }^{11}$

- Independence

- Authority or authority

- Wisdom

- Choice

- Decision

- Action

- Accuracy

Those eighth elements are formulated comprehensivelyin which discretion is: ${ }^{12}$

"Independence and/or authority (a person/group of people/institutions to - wisely and

\footnotetext{
${ }^{10}$ Ibid.

${ }^{11}$ Erlyn Indarti, Diskresi Kepolisian, Semarang, Badan Penerbit Universitas Diponegoro, 2000.
} 
considerately make choices in terms of making decisions and or taking the (certain) action that seem to bethe most appropriate."

These decision-making and action-taking are essentially the ends of a real long sequence of processes. The process involves the outpouring of wisdom which in this case also contains caution that is based on intellectual or adequate intellectual. The process also fairly involves consideration or assessment from all points of view. Afterwards, it leads to the choice of decision-making and/or taking certain actions. In terms of law enforcement, for example, the entire process can be understood as a series of attempts: ${ }^{13}$

- Reviewing the case at hand

- $\quad$ Reading the existing (legal) terms

- Interpreting such provisions further

- Sorting out the existing provisions as needed

- Choosing or setting options, i.e. in case of making a legal decision, and taking certain action.

Legal factors that cause sentence disparity are because in the positive law in Indonesia, judges are given freedom and allowed to widely determine the type of sentence. Muladi states that in addition to things that are originated in the law, there are other things that cause the disparity in which the factors derived from the judges themselves, both internal and external factors that cannot be separated because it has been billed as an attribute someone called human equation or personality of judge in a broad sense concerning the influence of social background, religious education, experience and social behavior.

\section{CONCLUSION}

The discretion applied by one judge to another will be different, in which this difference is based on the diversity of the paradigm he/she holds. The difference of the paradigm will create disparity in the judicial verdict. The disparity of judicial verdict is due to the paradigm that is embraced by the judge embedded within themselves. The diversity of the judge's paradigm will make a difference about the boundaries of the application of discretion which produce disparity in the judicial verdict.

\footnotetext{
${ }^{12}$ Ibid.

13 Ibid.
} 
Vol 2, No. (2019): Law, Development \& Justice Review, Mei 2019. e-ISSN: 2655-1942

This is very possible considering that the Judicial Power under the Law No. 48/2009 Article 18 is conducted by a Supreme Court and its subordinate courts within the courts of the General Courts, Religious Courts, Military Courts and State Administrative Courts and the Constitution Court.

\section{ACKNOWLEDGMENT}

Our great gratitude goes to the Faculty of Law of Diponegoro University which has granted permission to some Special Courts that have Adhoc judges in Indonesia in collecting data and interviews with judges, as well as give an opportunity to present the results of this research at the International Conference.

\section{REFERENCES}

Indarti, Erlyn, 2000, Diskresi Kepolisian, Semarang: Badan Penerbit Undip.

Indarti, Erlyn, 2010, Diskresi dan Paradigma. Badan Penerbit Universitas Diponegoro.

Manan, Bagir, Beberapa Catatan Tentang Penafsiran, varia peradilan nomor: 285 Agustus 2009.

Seno Adji, Oemar, 1984, Hukum-Hukum Pidana, Jakarta: Erlangga.

Seno Adji, Indriyanto, 2009, Humanis medan Pembaharuan Penegakan Hukum, Jakarta: Kompas.

Soekanto, Soeryono dan Purnadi Purwacaraka, 1985, Renungan Tentang Filsafat Hukum, Jakarta.

Soemarmi, Amiek. 2012. Pembentukan Pengadilan Perikanan Sebagai Upaya Pelaksanaan Penegakan Hukum di Bidang Perikanan. Hasil Penelitian Fakultas Hukum. Universitas Diponegoro. 